\title{
The extent of injection site infection in injecting drug users: findings from a national surveillance study
}

\author{
V. D. HOPE ${ }^{1,2 *}$, A. MARONGIU ${ }^{1}$, J. V. PARR Y ${ }^{1,2}$ AND F. NCUBE \\ ${ }^{1}$ Centre for Infections, Health Protection Agency, London, UK \\ ${ }^{2}$ Centre for Research on Drugs \& Health Behaviour, London School of Hygiene \& Tropical Medicine, \\ London, $U K$
}

(Accepted 15 January 2010; first published online 18 February 2010)

\begin{abstract}
SUMMARY
Injection site infections in injecting drug users (IDUs) are associated with serious morbidity and healthcare costs. Factors associated with symptoms of these were examined through annual (2006-2008) unlinked-anonymous survey of IDUs in England, Wales and Northern Ireland. Overall 36\% (1863/5209) self-reported having a symptom with no trend over time (35\% 2006, $37 \%$ 2007, 34\% 2008). Symptoms were less common in the North East of England; increased with years injecting; and were higher in women, those recently homeless, those recently using a needle exchange, and those injecting both opiates and stimulants. Of those injecting during the previous 4 weeks $(n=3733)$ symptoms were associated with: injecting daily; injecting $\geqslant 10$ times a day; injecting into hands, groin, or legs; sharing filters; and reusing water to flush syringes. Symptoms of injection site infections are common in IDUs. Better-targeted preventive interventions are needed, and continued surveillance should assist with assessing the impact of new initiatives.
\end{abstract}

Key words: Injecting drug-users (IDUs), skin infections, surveillance.

\section{INTRODUCTION}

Injection sites are susceptible to a wide range of bacterial infections; as result of poor hygiene injecting drug users (IDUs) are particularly vulnerable to such infections. These bacterial infections can result in illnesses ranging from localized infections of the skin and soft tissues, such as abscesses and cellulitus, to systemic and toxin-producing infections, such as endocarditis and botulism [1, 2]. These infections can be serious, requiring costly in-patient intervention and can also lead to death $[1,2]$. The prevalence of recent

* Author for correspondence: Dr V. D. Hope, Centre for Infections, Health Protections Agency, 61 Colindale Avenue, London, NW9 5EQ, UK.

(Email: vivian.hope@hpa.org.uk) or current skin and soft tissue infections in IDUs has been reported to be one in ten in Vancouver and Sydney [3, 4]; however, other studies from North America and in Europe indicate prevalence can be as high as one in three [5-8]. In North America these infections are the most common diagnoses in IDUs presenting to emergency departments $[9,10]$.

Injection site infections have been associated with poor hygiene and unsafe injection practices including: inadequate cleaning of the hands or the injection sites [11-13]; needle and syringe re-use $[8,11]$; frequent injection $[8,14-16]$; subcutaneous injection $[6,11]$; the injection sites used $[8,13,16]$; the drugs injected $[8$, $11,14,15]$; and drawing blood back into the syringe repeatedly [9]. Higher levels of these infections have also been reported to be associated with environmental factors, including poor housing and homelessness 
$[3,4,13]$, and with gender $[3,4,8,14]$ and source of income [4].

Since the start of the decade there has been increasing concern in the UK about the extent of bacterial infections in IDUs [17-19]. There has been a marked rise in hospital admissions by drug users with skin and soft tissue infections, e.g. admissions due to cutaneous abscesses of trunk or groin increased from 92 to $613(566 \%)$ between fiscal years 1997/1998 and 2003/2004 [19]. Annual reports of severe group A streptococcal infections in IDUs have increased more than tenfold from less than ten in the mid-1990s to 143 in 2004 [17], although reports have since declined [17]. There have been outbreaks of Clostridium novyi, tetanus and wound botulism in IDUs [20-22] in recent years. Community-acquired methicillin-resistant Staphylococcus aureus infection has also been reported in IDUs [23]. A community recruited study of IDUs in 2004 found that over a third (36\%) of IDUs in the seven sites sampled in England reported either an abscess or open wound at an injection site in the past year, and this study estimated a healthcare burden cost of between $£ 15.5$ and $£ 47$ million per annum [8]. These infections are thus likely to place a considerable burden on health services in the UK, as has been observed elsewhere $[5,6,16,24]$, and this may be increasing $[17,19]$.

In response to these concerns and the limited available data on the extent of, or the factors associated with, injection site infections in IDUs, the UK's national annual unlinked anonymous sero-behavioural survey of IDUs added in 2006 the collection of self-reported data on symptoms likely to be due to bacterial infection. Using data from this system for the period 2006-2008, this paper explores the prevalence and factors associated with self-reported symptoms of injection site infections in IDUs.

\section{METHODS}

IDUs have been recruited since 1990 into an annual voluntary unlinked-anonymous survey across England, Wales and Northern Ireland, methodological details of which have been previously published [25]. Briefly, drug agencies (both statutory and nonstatutory providers of advice, needle exchange, opiate substitution therapy, or addiction treatment) invite clients who have ever injected illicit drugs to participate in the annual surveys. Those drug users who agree to take part provide an oral fluid sample and self-complete a brief surveillance questionnaire. The oral fluid samples are tested for antibodies to HIV (anti-HIV), hepatitis C (anti-HCV) and hepatitis B core antigen (anti-HBc). The agency selection reflects the range of services provided for IDUs as well as reported geographic variations in the extent of injecting drug use, with the sampling structure reviewed regularly. The survey received multi-site approval from the London Research Ethics Committee.

The survey's questionnaire is reviewed regularly, and since 2006 it has collected information on selfreported symptoms of injection site infections. The following question was added: 'In the last year have you had a swelling containing pus (abscess), sore, or open wound at an injection site'. These symptoms are most likely to be due to a bacterial infection, although they could have other causes.

Those taking part in the survey between 2006 and 2008 inclusive, who completed the questionnaire and reported injecting illicit opiates (e.g. heroin) or stimulants (e.g. crack-cocaine, powder cocaine, or amphetamines) in the last year were included in the analyses. All analyses were undertaken in SPSS version 17 (SPSS Inc., USA). Univariate associations between the reporting of symptoms and the following variables were examined using the $\chi^{2}$ test: demographic, service use and environmental characteristics; the drugs used; region of recruitment; and survey year. Those characteristics found to be associated in the univariate analysis were then entered using the forward stepwise procedure in SPSS into a logistic regression model with inclusion assessed using the likelihood ratio (with the stepwise probability for inclusion of 0.05 and exclusion of $0 \cdot 1$ ). As information on injecting practice such as frequency of injection, equipment sharing, and the body sites used for injection was collected only from those who reported injecting in the 4 weeks prior to taking part in the survey (current IDUs) a second analysis examining associations between injecting practice and reported symptoms was undertaken using this subgroup.

\section{RESULTS}

Over the 3-year period there were 5209 participations by drug users who had injected illicit opiates or stimulants in the preceding year. Of these, $25 \%$ (1313) were female, $16 \%$ (821) were aged $<25$ years (mean age $32 \cdot 5$, median 32 years), and $24 \%$ (1230) had been injecting for $<5$ years (mean number of years since first injected 10.6, median 9). Just over two-thirds $(69 \%, 3570)$ reported currently receiving prescribed 
medication for their drug use (such as opiate substitution therapy), and $89 \%$ (4643) reported using a needle exchange service in the previous 12 months. Over half $(56 \%, 2898)$ had injected both opiates and stimulants during the last year, with two fifths ( $40 \%$, 2105 ) having injected only opiates and $4 \%$ (206) having injected only stimulants. During the year preceding participation 42\% (2194) reported being homeless and $35 \%$ (1315) reported having been imprisoned.

Overall, $36 \%$ (1863) report having a 'swelling containing pus (abscess), sore, or open wound' at an injection site during the previous 12 months. This varied little over the 3 -year period with $35 \%, 37 \%$ and $34 \%$ reporting this in 2006, 2007 and 2008, respectively (Table 1). Univariate associations between characteristics and the reporting of injection site symptoms are shown in Table 1. In the multivariable analysis a higher level of reported symptoms was found in 2007 compared to the other 2 years, suggesting a fluctuating level, but no trend, over time. Reporting symptoms was less common in the North East region compared to the other regions of England, Wales and Northern Ireland (Table 1). The reporting of symptoms increased with number of years injecting, and was higher in women, those recently homeless, those having recently used a needle exchange service, and those reporting injecting both opiates and stimulants, but lower in those only injecting stimulants (Table 1).

There were 3733 participations by those who reported last injecting during the preceding 4 weeks, representing $72 \%$ of those who had injected during the 12 months prior to participation. Of these current IDUs, $24 \%$ (913) were female, $17 \%$ (623) were aged $<25$ years (mean age $32 \cdot 3$, median 32 years), and $24 \%$ (893) had been injecting for $<5$ years (mean number of years since first injected $10 \cdot 4$, median 9). Those who had injected in the last month had similar levels of imprisonment and homelessness as those who had not. However, more of them had used a needle exchange $\left(93 \%\right.$ vs. $80 \%, \chi_{(1)}^{2}=179 \cdot 5, P<$ $0 \cdot 001$ ), fewer of them were currently receiving prescribed treatment for their drug use $(66 \%$ vs. $75 \%$, $\left.\chi_{(2)}^{2}=51 \cdot 9, P<0 \cdot 001\right)$, and more of them were injecting both opiates and stimulants $(58 \%$ vs. $49 \%$, $\left.\chi_{(2)}^{2}=36 \cdot 1, P<0 \cdot 001\right)$.

Of those who had injected during the preceding 4 weeks $37 \%$ (1375) reported having a 'swelling containing pus (abscess), sore, or open wound' at an injection site during the previous 12 months. The associations between reporting a symptom in the last year and reported injecting practice in the last month are shown in Table 2. In the multivariable analysis higher levels of reported symptoms were associated with the following injecting practices: injecting daily; injecting $\geqslant 10$ times a day; injecting into the hand, groin, or legs; sharing filters; and reusing water to flush syringes (Table 2).

\section{DISCUSSION}

Symptoms of injection site infections are common in IDUs throughout England, Wales and Northern Ireland. These symptoms were reported by just over a third of IDUs, and while the level fluctuated over the 3 years examined, there was no clear trend. These symptoms were associated with injecting both opiates and stimulants, having been injecting for a long time, being female, homeless, and with recent use of a needle exchange. Symptoms were also associated with more frequent injection, use of particular body sites for injection, and the reuse of filters and flushing water.

The high prevalence of self-reported injection site infections found in this study, supports previous finding from England [8] and also elsewhere [3-7]. The costs associated with injection site infections are considerable, with conservative estimates for England suggesting total costs of at least $£ 15.5-19.5$ million per annum, but possibly as high as $£ 47$ million in 2006 . Overall healthcare costs related to problematic drug use, both injecting and non-injecting, in England have been estimated to be around $£ 500$ million per annum in the financial year 2003/2004 [26], with $£ 25$ million of this due to bloodborne viruses (HIV, hepatitis B and C) in IDUs.

Injection site infections thus place a considerable burden on the healthcare system that may be greater than that due to infections by bloodborne viruses. The high costs associated with injection site bacterial infections are in part likely to be due to delays in seeking healthcare. Studies suggest that IDUs tend not to seek timely medical care for their injecting-related health problems, often resulting in emergency treatment at considerable cost $[8,10,24,27,28]$. The failure to seek earlier treatment probably reflects obstacles, e.g. barriers to accessing care and poor compliance with medication and follow-up care, and competing priorities such as obtaining money and acquiring and using drugs $[10,24,28,29]$. Thus, the high levels of reported symptoms found here are a concern and highlight the need for interventions. Targeted prevention 
Table 1. Factors associated with a self-reported abscess, sore or open wound at injecting site in the previous 12 months: injecting drug users, 2006-2008

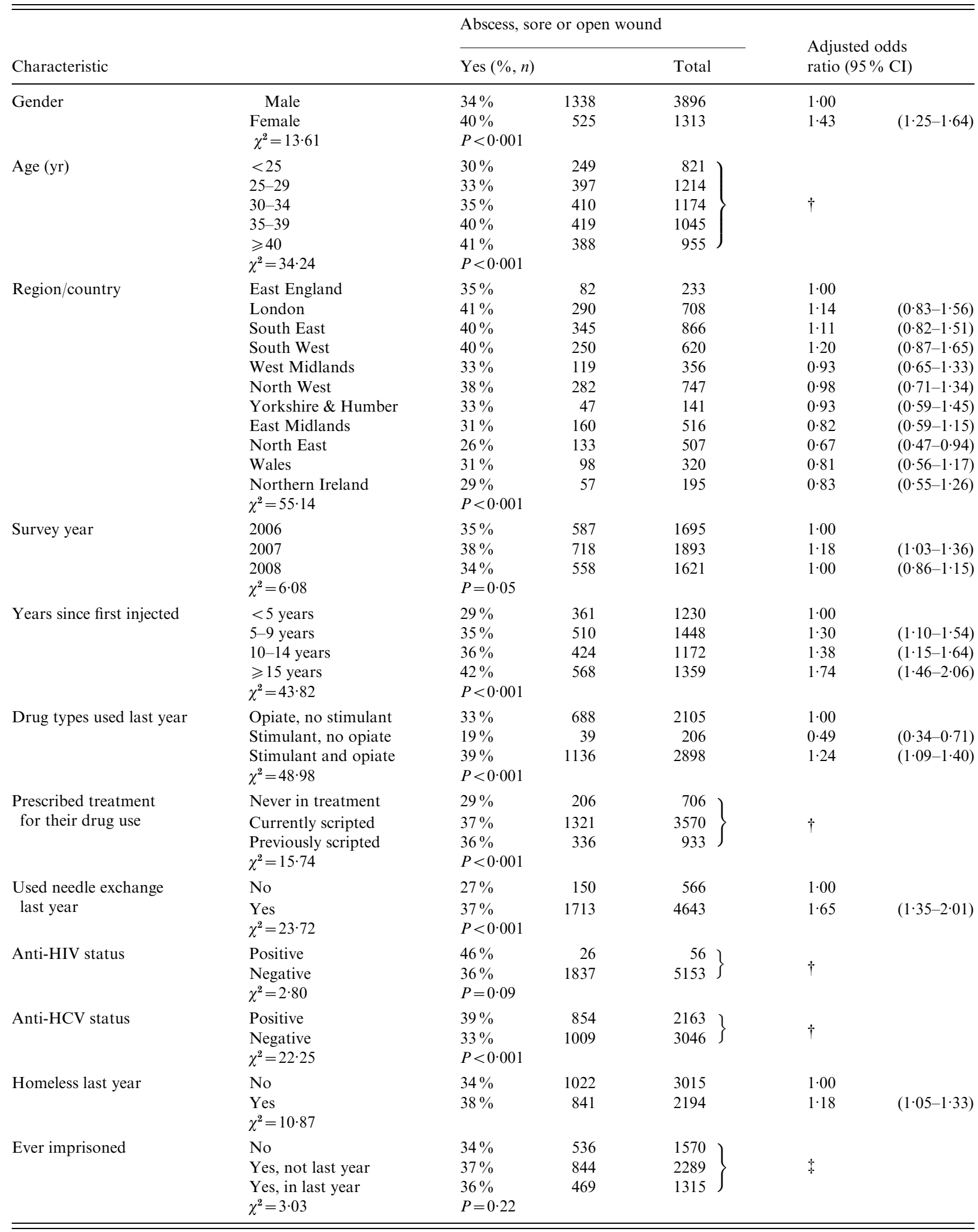

CI, Confidence interval.

$\dagger$ Not in final multivariable model.

\$ Not entered into multivariable analysis. 
Table 2. Injecting practices is last month associated with a self-reported abscess, sore or open wound at injecting site during the previous 12 months, injecting drug users 2006-2008

\begin{tabular}{|c|c|c|c|c|c|c|}
\hline \multirow[b]{2}{*}{ Characteristic } & & \multicolumn{3}{|c|}{ Abscess, sore or open wound } & \multirow{2}{*}{\multicolumn{2}{|c|}{$\begin{array}{l}\text { Adjusted odds } \\
\text { ratio }(95 \% \mathrm{CI})\end{array}$}} \\
\hline & & Yes $(\%, n$ & & Total & & \\
\hline Times injected last full day & $\begin{array}{l}\quad 1 \\
2-4 \\
5-9 \\
\geqslant 10 \\
\chi^{2}=52 \cdot 20\end{array}$ & $\begin{array}{l}30 \% \\
38 \% \\
45 \% \\
64 \% \\
P<0 \cdot 001\end{array}$ & $\begin{array}{r}321 \\
856 \\
159 \\
39\end{array}$ & $\begin{array}{r}1068 \\
2252 \\
352 \\
61\end{array}$ & $\begin{array}{l}1 \cdot 00 \\
1 \cdot 14 \\
1 \cdot 32 \\
2 \cdot 99\end{array}$ & $\begin{array}{l}(0 \cdot 95-1 \cdot 36) \\
(0 \cdot 99-1 \cdot 76) \\
(1 \cdot 65-5 \cdot 44)\end{array}$ \\
\hline $\begin{array}{l}\text { Number of days injected } \\
\text { last } 4 \text { weeks }\end{array}$ & $\begin{array}{l}<14 \\
14-27 \\
\geqslant 28 \\
\chi^{2}=28 \cdot 77\end{array}$ & $\begin{array}{l}32 \% \\
36 \% \\
41 \% \\
P<0.001\end{array}$ & $\begin{array}{l}411 \\
285 \\
679\end{array}$ & $\begin{array}{r}1291 \\
800 \\
1642\end{array}$ & $\begin{array}{l}1 \cdot 00 \\
1 \cdot 07 \\
1 \cdot 23\end{array}$ & $\begin{array}{l}(0 \cdot 87-1 \cdot 31) \\
(1 \cdot 03-1 \cdot 48)\end{array}$ \\
\hline $\begin{array}{l}\text { Shared needles and } \\
\text { syringes last } 4 \text { weeks }\end{array}$ & $\begin{array}{l}\text { No } \\
\text { Yes } \\
\chi^{2}=24.62\end{array}$ & $\begin{array}{l}35 \% \\
44 \% \\
P<0 \cdot 001\end{array}$ & $\begin{array}{r}1014 \\
361\end{array}$ & $\left.\begin{array}{r}2917 \\
816\end{array}\right\}$ & $\dagger$ & \\
\hline Shared spoons last 4 weeks & $\begin{array}{l}\text { No } \\
\text { Yes } \\
\chi^{2}=44 \cdot 34\end{array}$ & $\begin{array}{l}33 \% \\
44 \% \\
P<0 \cdot 001\end{array}$ & $\begin{array}{l}767 \\
608\end{array}$ & $\left.\begin{array}{l}2340 \\
1393\end{array}\right\}$ & $\dagger$ & \\
\hline Shared filters last 4 weeks & $\begin{array}{l}\text { No } \\
\text { Yes } \\
\chi^{2}=51 \cdot 61\end{array}$ & $\begin{array}{l}33 \% \\
45 \% \\
P<0.001\end{array}$ & $\begin{array}{l}831 \\
544\end{array}$ & $\begin{array}{l}2525 \\
1208\end{array}$ & $\begin{array}{l}1 \cdot 00 \\
1 \cdot 31\end{array}$ & $(1 \cdot 09-1 \cdot 59)$ \\
\hline $\begin{array}{l}\text { Shared water for drug } \\
\text { preparation last } 4 \text { weeks }\end{array}$ & $\begin{array}{l}\text { No } \\
\text { Yes } \\
\chi^{2}=26 \cdot 12\end{array}$ & $\begin{array}{l}35 \% \\
45 \% \\
P<0.001\end{array}$ & $\begin{array}{r}1068 \\
307\end{array}$ & $\left.\begin{array}{r}3057 \\
676\end{array}\right\}$ & $\dagger$ & \\
\hline $\begin{array}{l}\text { Shared water for flushing } \\
\text { works last } 4 \text { weeks }\end{array}$ & $\begin{array}{l}\text { No } \\
\text { Yes } \\
\chi^{2}=40 \cdot 21\end{array}$ & $\begin{array}{l}34 \% \\
46 \% \\
P<0 \cdot 001\end{array}$ & $\begin{array}{l}996 \\
379\end{array}$ & $\begin{array}{r}2914 \\
819\end{array}$ & $\begin{array}{l}1 \cdot 00 \\
1 \cdot 28\end{array}$ & $(1 \cdot 03-1 \cdot 59)$ \\
\hline Injected into arms last 4 weeks & $\begin{array}{l}\text { Yes } \\
\text { No } \\
\chi^{2}=4 \cdot 54\end{array}$ & $\begin{array}{l}36 \% \\
39 \% \\
P=0.03\end{array}$ & $\begin{array}{l}836 \\
539\end{array}$ & $\left.\begin{array}{l}2352 \\
1381\end{array}\right\}$ & $\dagger$ & \\
\hline Injected in to hands last 4 weeks & $\begin{array}{l}\text { Yes } \\
\text { No } \\
\chi^{2}=65 \cdot 32\end{array}$ & $\begin{array}{l}48 \% \\
33 \% \\
P<0 \cdot 001\end{array}$ & $\begin{array}{l}448 \\
927\end{array}$ & $\begin{array}{r}936 \\
2797\end{array}$ & $\begin{array}{l}1 \cdot 54 \\
1 \cdot 00\end{array}$ & $(1 \cdot 29-1 \cdot 82)$ \\
\hline Injected in to groin last 4 weeks & $\begin{array}{l}\text { Yes } \\
\text { No } \\
\chi^{2}=5 \cdot 07\end{array}$ & $\begin{array}{l}39 \% \\
36 \% \\
P=0.02\end{array}$ & $\begin{array}{l}491 \\
884\end{array}$ & $\begin{array}{l}1248 \\
2485\end{array}$ & $\begin{array}{l}1 \cdot 28 \\
1 \cdot 00\end{array}$ & $(1 \cdot 09-1 \cdot 51)$ \\
\hline Injected in to legs last 4 weeks & $\begin{array}{l}\text { Yes } \\
\text { No } \\
\chi^{2}=234 \cdot 33\end{array}$ & $\begin{array}{l}62 \% \\
31 \% \\
P<0 \cdot 001\end{array}$ & $\begin{array}{l}426 \\
949\end{array}$ & $\begin{array}{r}683 \\
3,050\end{array}$ & $\begin{array}{l}3 \cdot 24 \\
1 \cdot 00\end{array}$ & $(2 \cdot 69-3 \cdot 90)$ \\
\hline Injected in to feet last 4 weeks & $\begin{array}{l}\text { Yes } \\
\text { No } \\
\chi^{2}=92 \cdot 11\end{array}$ & $\begin{array}{l}58 \% \\
34 \% \\
P<0 \cdot 001\end{array}$ & $\begin{array}{r}245 \\
1130\end{array}$ & $\left.\begin{array}{r}422 \\
3311\end{array}\right\}$ & $\dagger$ & \\
\hline Gender & $\begin{array}{l}\text { Male } \\
\text { Female } \\
\chi^{2}=15 \cdot 40\end{array}$ & $\begin{array}{l}35 \% \\
42 \% \\
P<0.001\end{array}$ & $\begin{array}{l}989 \\
386\end{array}$ & $\begin{array}{r}2820 \\
913\end{array}$ & $\begin{array}{l}1 \cdot 00 \\
1 \cdot 41\end{array}$ & $(1 \cdot 19-1 \cdot 66)$ \\
\hline Region/country & $\begin{array}{l}\text { East England } \\
\text { London } \\
\text { South East } \\
\text { South West } \\
\text { West Midlands } \\
\text { North West } \\
\text { Yorkshire \& Humber } \\
\text { East Midlands } \\
\text { North East } \\
\text { Wales } \\
\text { Northern Ireland } \\
\chi^{2}=58.41\end{array}$ & $\begin{array}{l}34 \% \\
45 \% \\
41 \% \\
40 \% \\
36 \% \\
40 \% \\
36 \% \\
30 \% \\
25 \% \\
31 \% \\
36 \% \\
P<0 \cdot 001\end{array}$ & $\begin{array}{r}48 \\
205 \\
272 \\
182 \\
99 \\
224 \\
27 \\
121 \\
105 \\
62 \\
30\end{array}$ & $\begin{array}{r}142 \\
458 \\
660 \\
454 \\
278 \\
561 \\
74 \\
406 \\
415 \\
201 \\
84\end{array}$ & $\begin{array}{l}1 \cdot 00 \\
1 \cdot 52 \\
1 \cdot 32 \\
1 \cdot 27 \\
1 \cdot 26 \\
1 \cdot 40 \\
1 \cdot 31 \\
0 \cdot 82 \\
0 \cdot 73 \\
0 \cdot 99 \\
1 \cdot 67\end{array}$ & $\begin{array}{c}(1 \cdot 00-2 \cdot 33) \\
(0 \cdot 88-1.98) \\
(0 \cdot 83-1.94) \\
(0 \cdot 80-1 \cdot 98) \\
(0 \cdot 93-2 \cdot 12) \\
(0 \cdot 70-2 \cdot 46) \\
(0 \cdot 53-1 \cdot 27) \\
(0 \cdot 47-1 \cdot 14) \\
(0 \cdot 61-1.62) \\
(0.92-3.03)\end{array}$ \\
\hline
\end{tabular}


Table 2 (cont.)

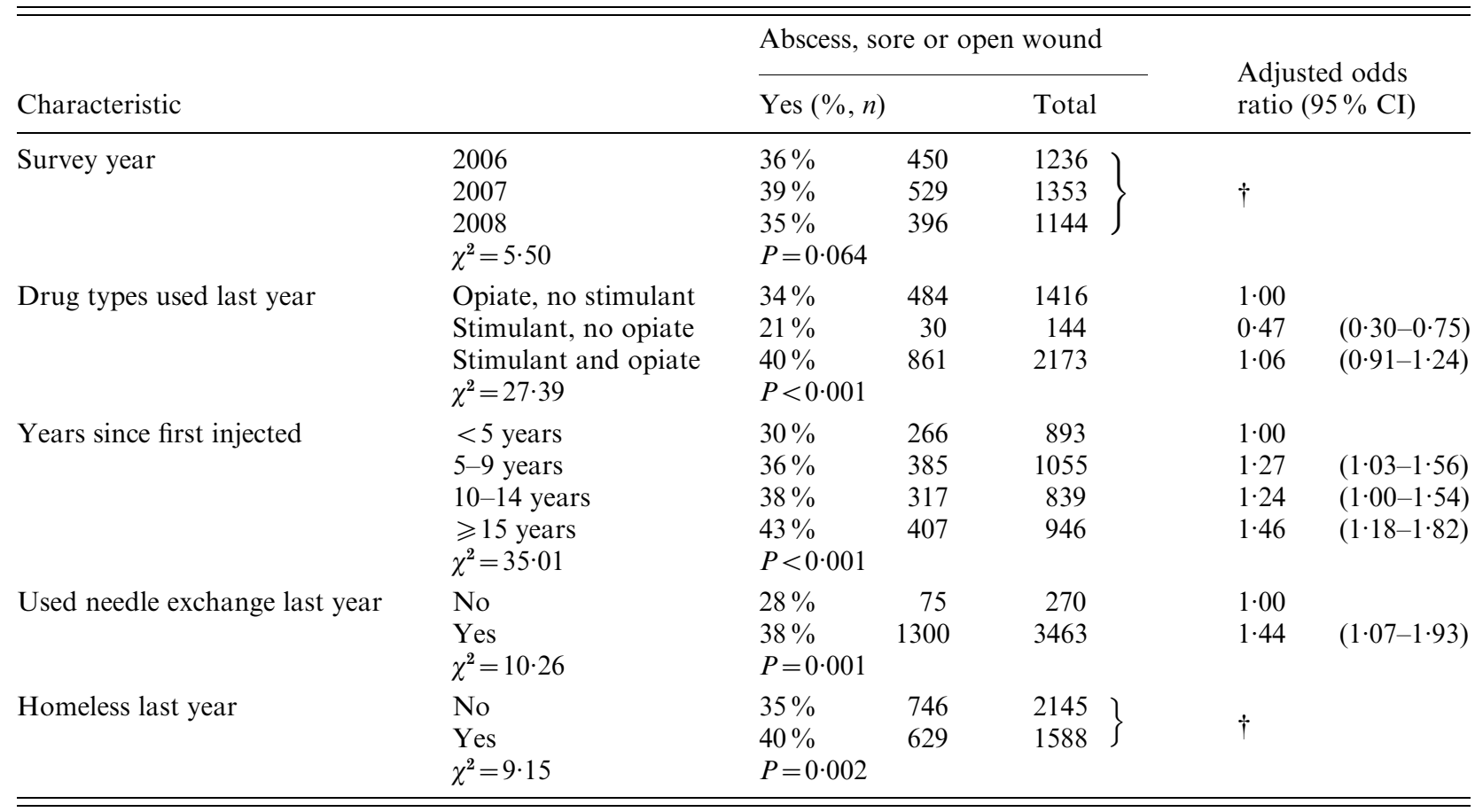

CI, Confidence interval.

$\dagger$ Not in final multivariable model.

and healthcare have been shown to reduce emergency department attendances, the need for surgery, and inpatient days [30, 31].

The current study found that frequent injection, the use of certain injection sites (hand, groin, legs), and the reuse of injecting paraphernalia were all associated with reporting symptoms of injection site infections during the last year. Previous studies have found similar associations $[8,11,12,14,15]$, and also associations with inadequate washing of hands or cleaning of the injection sites [6,11, 12], and the use of multiple injection sites [11, 12]. The associations with particular injection sites needs further examination, but may reflect some of these sites being more difficult to keep clean or the need to use certain sites due to others becoming unusable due to vascular damage, injury, or infection. The association with femoral ('groin') injection in the current study is of particular concern as this practice has become more common in the UK over the last decade [32], with indications of increased hospital admissions related to femoral injection in IDUs [19].

The association with injecting both opiates and stimulants is a concern. The mostly widely injected stimulant in the UK is crack-cocaine, with this often being injected either in combination or in parallel with heroin. A previous study in England found that those reporting crack-cocaine use also reported higher levels of injection site infections, and studies elsewhere have observed similar associations with injection of cocaine $[7,10]$ and heroin and cocaine combinations $[11,15]$. There is also evidence that suggests that crack-cocaine use, which has been associated with risky behaviours [32, 33], has become more common in the UK in recent years [34].

Women were more likely to report an injection site infection, and this has also been found in other studies $[7,8,11,15]$. This could reflect a greater awareness of infections, and/or a greater vulnerability to injection site infections in female injectors [14]. As women are more likely to be injected by others, or to need assistance with injecting, it has been argued that as a result they may be at increased risk of exposure to contaminants [4]. The reason for the difference in prevalence with gender needs further investigation.

The positive association with needle exchange use in the last year is an interesting, if counter-intuitive, finding. However, this needs to be interpreted with care as those reporting needle exchange use in the last year will include not only those making extensive regular use of needle exchange services but also those making irregular or limited use of these services. 
Studies suggest the consistent high coverage of interventions like needle exchange is needed for them to be effective against bloodborne viruses [35-37], and it is likely that such coverage issues would similarly affect their impact on injection site infections. It should also be noted that not all needle exchanges in the UK provide a full range of injecting equipment, and that some IDUs may also have accessed a needle exchange service either as a route to wound care or as a preventive measure following an injection site infection. However, this association requires further examination.

In our study homelessness was associated with higher rates of reporting of injection site symptoms, while a previous study in England did not find any association with homelessness [8]. Studies elsewhere have found similar associations with poor housing and homelessness $[3,4,13]$. Homelessness is possibly an indicator of increased rates of injection in public or semi-public environments, which has been related to poor injection hygiene [11, 12].

Preventive interventions should thus focus on further reducing the re-use of injecting equipment, and target frequent injectors, those injecting into groin, legs or hand, using both opiates and stimulants, and female injectors; these interventions should also aim to reach those who are homeless. Development of community-based interventions, such as targeted wound clinics, may be effective [30, 31]. While further work needs to identify, develop, and evaluate suitable interventions, our findings suggest a need to focus on improving injection hygiene, the better management of the body sites used for injection, and access to services, including the provision of paraphernalia and sterile water.

The 3 years' data presented here did not indicate any overall upwards or downwards trend in symptoms associated with injection site infection, with the level much the same as that found in a study of current IDUs recruited in the community at seven sites in England conducted 2 years earlier [8]. This suggests that the recent level of symptoms may have been relatively stable; however, this may not remain so. The concerns expressed earlier this decade about the extent of infections in IDUs [17-19, 21-23] have resulted in increased efforts to reduce infections, both viral and bacterial. The National Institute for Health and Clinical Excellence has recently issued guidance on optimizing needle exchange provision [38] and a national awareness and information campaign has recently been launched in England [39]. Ongoing surveillance of symptoms of injection site infections may shed light on the impact of these initiatives.

It is important to consider the limitations and generalizability of these findings. Self-reported symptoms of injection site infections were used in this study. While some may question the accuracy of these, studies have shown good agreement between selfreported symptoms and clinical diagnosis [24]. The comparative rarity, marginalization and illegal nature of injecting drug use impedes the recruitment of a representative sample of injectors. This study aimed to minimize sampling biases and maximize representativeness by using an established survey utilizing widespread service provision as a sampling structure. However, bias might arise if those using services where the sampling occurred were either at higher or lower risk than the overall IDU population. Those not in contact with services might be those most marginalized and so at highest risk but, alternatively, they may be those most stable and integrated with well-controlled drug use and so at low risk. Both of these groups are possibly under-represented; however, surveys recruiting independently of services through community settings, using a range of sampling approaches, find that most IDUs recruited in the UK have, or have recently had, service contact [40].

Taken together these findings suggest injection site infections are a common experience in IDUs in England, Wales and Northern Ireland, and that the resultant healthcare burden is substantial. Further research is also needed to explore issues around the robustness of self-reports and the relationship between reported symptoms and actual infections. Moreover, interventions need to be developed and piloted to reduce the level of infections. Continued surveillance should provide the means to shed light on the impact of new initiatives to reduce infections in IDUs.

\section{ACKNOWLEDGEMENTS}

This work was support by core funding to the Health Protection Agency. We are grateful to all of the injecting drug users who took part in the survey and to the staff of many services that assisted with their recruitment. We thank those who undertook the bloodborne virus testing on the samples, in particular Bharati Patel, and those who have assisted with the running survey, particularly Merrington Omakalwala and Jacquelyn Njoroge. 


\section{DECLARATION OF INTEREST}

None.

\section{REFERENCES}

1. Cherubin C, Sapira J. The medical complications of drug addiction and the medical assessment of the intravenous drug user. Annals of Internal Medicine 1993; 119: 1017-1028.

2. Del Guidice $\mathbf{P}$. Cutaneous complication of intravenous drug abuse. British Journal of Dermatology 2004; 150: $1-10$.

3. Lloyd-Smith E, et al. Risk factors for developing a cutaneous injection-related infection among injection drug users: a cohort study. BMC Public Health 2008; 8: 405.

4. Salmon AM, et al. Injecting-related injury and disease among clients of a supervised injecting facility. Drug \& Alcohol Dependence 2009; 101 : 132-136.

5. Takahasi T, et al. Type and location of injection drug use-related soft tissue infections predict hospitalization. Journal of Urban Health 2003; 80: 127-136.

6. Biswanger I, et al. High prevalence of abscesses and cellulitis among community-recruited injection drug users in San Fransisco. Clinical Infectious Diseases $2000 ; 30$ : 579-581.

7. Lloyd-Smith E, et al. Prevalence and correlates of abscesses among a cohort of injection drug users. Harm Reduction Journal 2005; 2 : 24.

8. Hope $\mathbf{V}$, et al. Frequency, factors and costs associated with injection site infections: findings from a national multi-site survey of injecting drug users in England. BMC Infectious Diseases 2008; 8: 120.

9. Kerr T, et al. High rates of primary care and emergency department use among injection drug users in Vancouver. Journal of Public Health (Oxford) 2005; 27: 62-66.

10. Palepu A, et al. Hospital utilization and costs in a cohort of injection drug users. Canadian Medical Association Journal 2001; 165: 415-420.

11. Murphy E, et al. Risk factors for skin and soft-tissue abscesses among injection drug users: a case-control study. Clinical Infectious Diseases 2001; 33: 35-40.

12. Vlahov D, et al. Bacterial infections and skin cleaning prior to infection among intreavenous drug users. Public Health Reports 1992; 107: 595-598.

13. Dwyer R, et al. Prevalences and correlates of non-viral injecting-related injuries and diseases in a convenience sample of Australian injecting drug users. Drug \& Alcohol Dependence 2009; 100: 9-16.

14. Topp L, et al. Prevalence and predictors of injectingrelated injury and disease among clients of Australia's needle and syringe programs. Australia \& New Zealand Journal of Public Health 2008; 32: 34-37.

15. Spijkerman I, van Ameijden EJ, Mientjes G. Human immunodeficiency virus and other risk factors for skin abscesses and endocarditis among injection drug users. Journal of Clinical Epidemiology 1996; 49: 1149-1154.
16. Darke S, Ross J, Kaye S. Physical injecting sites among injecting drug users in Sydney, Australia. Drug \& Alcohol Dependence 2001; 62: 77-82.

17. Health Protection Agency, Health Protection Scotland, National Public Health Service for Wales, CDSC Northern Ireland, CRDHB, and the UASSG. Shooting Up : Infections Among Injecting Drug Users in the United Kingdom 2007. London: Health Protection Agency, October, 2008.

18. Lamagni TL, et al. Severe Streptococcus pyogenes infections, United Kingdom, 2003-2004. Emerging Infectious Diseases 2008; 14: 202-209.

19. Irish C, et al. Skin and soft tissue infections and vascular disease among drug users, England [Letter]. Emerging Infectious Diseases 2007; 13 (October).

20. Jones JA, et al. An outbreak of serious illness and death among injecting drug users in England and Wales during 2000. Journal of Medical Microbiology, 2002; 51: 978-984.

21. Beeching, NJ, Crowcroft NS. Tetanus in injecting drug users. The latest Clostridium infection to threaten injectors in Britain. British Medical Journal 2005; 330: 208-209.

22. Akbulut D, et al. Outbreak report: Wound botulism in injectors of illicit drugs: upsurge in cases in England during 2004. Eurosurveillance Monthly 2005; 10 (September).

23. Kearns AM, et al. An unusual clone of MRSA causing infection in injecting drug users. Journal of Infection 2004; 49: 49-50.

24. Morrison A, Elliott L, Gruer L. Injecting-related harm and treatment seeking behaviour among injecting drug users. Addiction 1997; 92: 1349-1352.

25. Noone A, et al. HIV infection in injecting drug users attending centres in England and Wales, 1990-1991. AIDS 1993; 7: 1501-1507.

26. Gordon L, et al. The Economic and Social Costs of Class A Drug use in England and Wales, 2003/04. In: Singleton N, Murray R, Tinsley L, eds. Measuring different aspects of problem drug use: methodological developments. London, Home Office, 2006. Home Office Online Report, 16/06.

27. Ciccarone D, et al. Soft tissue infections among injection drug users-San Francisco, California, 1996-2000. Morbidity \& Mortality Weekly Reports: CDC Surveillance Summaries 2001 ; 50: 381-384.

28. French M, et al. Chronic illicit drug use, health services utilisation and the cost of medical care.Social Science \& Medicine 2000; 50: 1703-1713.

29. van Beek I, Dwyer R, Malcom A. Cocaine injecting: the sharp end of drug related harm! Drug \& Alcohol Review 2001; 20 (Harm Reduction Digest 14): 333342.

30. Harris H, Young D, Organ Jr. C. Care of injection drug users with soft tissue infections in San Fransisco, California. Archives of Surgery 2002; 137: 12171222.

31. Grau L, et al. Expanding harm reduction services through a wound and abscess clinic. American Journal of Public Health 2002; 92: 1915-1917. 
32. Rhodes T, et al. Groin injecting in the context of crack cocaine and homelessness: From 'risk boundary' to 'acceptable risk'? International Journal of Drug Policy 2006; 17: 164-170.

33. Rhodes T, et al. Crack-heroin speedball injection and its implications for vein care: qualitative study. Addiction 2007; 102: 1782-1789.

34. Hope VD, Hickman M, Tilling K. Capturing crackcocaine use: Estimating the prevalence of Crackcocaine use in London using capture-recapture with covariates. Addiction 2005; 100: 1701-1708.

35. Van Den Berg C, et al. Full participation in harm reduction programmes is associated with decreased risk for human immunodeficiency virus and hepatitis $\mathrm{C}$ virus: evidence from the Amsterdam Cohort Studies among drug users. Addiction 2007; 102: 1454-1462.

36. Vickerman P, Hickman M, Judd A. Modelling the impact on hepatitis $\mathrm{C}$ transmission of reducing syringe sharing: London case study. International Journal of Epidemiology 2007; 36: 396-405

37. Craine N, et al. Incidence of hepatitis $C$ in drug injectors: the role of homelessness, opiate substitution treatment, equipment sharing, and community size. Epidemiology and Infection 2009; 137: 1255-1265.

38. NICE. Needle and syringe programmes: providing people who inject drugs with injecting equipment. National Institute for Health and Clinical Excellence, Public Health Guidance, PH18, February 2009 (http:// guidance.nice.org.uk/PH18).

39. Harm Reduction Works. National Treatment Agency for Substance Use and Exchange Supplies. (www. harmreductionworks.org.uk/). Accessed 17 August 2009.

40. Hickman M, et al. Hepatitis C (HCV) prevalence, and injecting risk behaviour in multiple sites in England in 2004. Journal of Viral Hepatitis 2007; 14: 645-652. 